\title{
Trauma srca (tamponada srca-perikarda)
}

\section{Cardiac Trauma (cardiac-pericardium tamponade)}

\author{
Greta Cindrić Bogdan* \\ Kardiološka poliklinika "Bogdan", Zagreb, Hrvatska \\ Bogdan Cardiology Polyclinic, Zagreb, Croatia
}

SAŽETAK: Prikazani su najčešći uzroci traume srca s posebnim osvrtom i definicijom nepenetrantne - tupe i penetrantne - oštre ozljede, obje česte u tijeku traume prsnog koša. Opisane su tamponada srca i kontuzija miokarda. Navedeni su simptomi, klinička slika, patomorfološka-patofiziološka zbivanja oba entiteta. Ukazano je na važnost brze intervencije na mjestu nesreće, incidenta, osobito kod penetrantne traume srca. Istaknuti su značenje prehospitalne skrbi za pacijenta kao i potreba visoke stručnosti ekipe hitne medicinske pomoći uz primjenu transtorakalnog ehokardiografskog pregleda na mjestu incidenta. Naglašena je potreba da se uz ehokardiografiju primijeni i terapijska perikardiocenteza kao važan zahvat na mjestu incidenta, ali s velikim oprezom u pojedinoj penetrantnoj ozljedi srca, u cilju sprječavanja razvitka tamponade srca. Istaknute su dijagnostičke mogućnosti instrumentalnih pretraga srca i prsnog koša u hospitalnom razdoblju, u ocjeni osobito tupe nepenetrantne traume srca.

KLJUČNE RIJEČl: trauma srca, tamponada perikarda, transtorakalna ehokardiografija, terapijska perikardiocenteza.

\section{Uvod}

Ovaj je pregled potaknut epidemijom prometnih nesreća motornim vozilima u Hrvatskoj s traumom prsnog koša i srca te učestalim smrtnim ishodom kod nekih sportova kod kojih postoji i trauma prsnog koša, pa time i mogućnost traume srca. Povećana učestalost traume srca je češća u našim društveno-gospodarskim uvjetima života još uvijek i primjenom hladnog oružja. Ova problematika se ne može zanemariti obzirom na učestalost posjedovanja vatrenog oružja budući to predstavlja potencijalni pojedinačni izvor penetrantnih srčanih ozljeda sa smrtnim ishodom.

Smatra se da je oko 25\% svih traumatskih ozljeda prsnog koša koje završavaju smrtno uzrokovano upravo oštećenjem srca'. Statistički podaci pokazuju da je najčešće zahvaćena desna klijetka (DV; u 35\%), a potom slijede lijeva kljetka (LV; u 25\%), desna pretklijetka (DA; u 33\%) te lijeva pretklijetka (LA; u 14\%) ${ }^{1}$. Drugi statistički podaci iznose incidenciju oštećenja desnog dijela srca kod traume srca od
SUMMARY: The most common causes of cardiac trauma, with special regard to nonpenetrating - blunt and penetrating - sharp injuries, frequent in the course of thoracal injury, and their definitions are presented. Symptoms, clinical course and patomorphologic-pathophysiological events in cardiac tamponade and myocardial contusion are described. The importance of rapid intervention at the spot, especially in penetrating cardiac trauma is stressed. Special significance is given to prehospital care and accordingly the need for highly educated teams of first aid with the application of transthoracic echocardiography on the spot of the incident as diagnostic method. Beside echocardiography, a need for careful application of therapeutic pericardiocentesis as urgent intervention as an important procedure at the place of accident with the aim of prevention of fatal outcome due to pericardial tamponade is strongly pointed. Diagnostic possibilities of instrumental heart and thorax check-ups during hospital stay, especially in evaluation of blunt - nonpenetrating cardiac trauma is described.

KEYWORDS: cardiac trauma, pericardial tamponade, transthoracic echocardiogragraphy, therapeutic cardiocentesis.

CITATION: Cardiol Croat. 2013;8(10-11):331-344.

\section{Introduction}

This review has been prompted by an epidemic of car accidents in Croatia with thoracic and cardiac trauma and frequent fatal outcome in some sports associated with thoracic trauma, and thus the possibility of cardiac trauma. An increased incidence of cardiac trauma is more common in our socio-economic living conditions still due to using cold weapons. This problem can not be ignored considering the prevalence of possession of firearms which is a potential individual source of penetrating cardiac injuries with fatal outcome.

The exact cause of about $25 \%$ of all thoracic traumas with deadly outcome is the cardiac injury ${ }^{1}$. Statistical data show that the right ventricle ( $\mathrm{RV}$; in $35 \%$ ) is the most frequently affected, followed by left ventricle (LV; in $25 \%$ ), the right atrium (RA; in $33 \%$ ) and the left atrium (LA; in 14\%). Some other statistical data report on the incidence of injury of the right part of the heart in cardiac trauma of $76 \%$ and left part of $14.3 \%{ }^{2}$. In addition to the cardiac injury, thoracic trauma 
$76 \%$, a lijevog od $14,3 \%{ }^{2}$. Uz oštećenje srca kod traume prsnog koša često je prisutno i oštećenje drugih organskih sustava: pluća, pleure, medijastinuma, traheje, bronha, ezofagusa, rebara, aortne stijenke, kralježnice, što doprinosi nastanku kompleksne simptomatologije te stvara diferencijalno dijagnostičke poteškoć $e^{1,3-5}$.

Izvješća svjetskih traumatoloških centara osim potrebe neposredne hitne intervencije "na licu mjesta" naglašavaju važnost brze informiranosti i spremnosti ekipe kirurškog centra, što bi trebalo omogućiti učinkovitu hospitalnu intervenciju.

Usprkos neposrednoj pomoći i hitnoj intervenciji na mjestu incidenta, a potom analize te hospitalnog liječenja, traumatsko oštećenje srčanih struktura s tamponadom perikarda i dalje ima visoku incidenciju smrtnosti u prometnim nesreća$\mathrm{ma}-20 \%{ }^{6}$. Na intervenciju kod penetrantnih ozljeda srca u kirurškim centrima otpada mali broj, svega 0,5\% svih kirurškh intervencija ${ }^{5}$. Čini se da mnogi pacijenti ne stignu do stručne specijalističke pomoći, a uzrok tome je možda i činjenica da hitna medicinska pomoć na terenu nije opskrbljena adekvatnom aparaturom ili nije u stanju dijagnosticirati i pružiti adekvatnu pomoć. Traume srca - nepenetrantne i penetrantne, u nesrećama s motornim vozilima se javljaju u visokoj zajedničkoj incidenciji od $80 \%$ do $90 \%$. Nepenetrantne ozljede ne moraju biti odmah smrtonosne, ali se u daljnjem praćenju često kompliciraju lošim ishodom, a smrtnost u duljem posthospitalnom periodu također je visokih $57 \%$ do $64 \%{ }^{8}$.

\section{Definicija i uzroci}

Srčana trauma se dijeli na:

- nepenetrantnu - tupu povredu srca - bez neposredno vidljivog oštećenja (rane, laceracije) na prsnom košu, ali moguće posredno utvrđenim kasnije unutrašnjim oštećenjima na srcu, aorti i ev. drugim organima;

- akutnu penetrantnu - oštru povredu srca (ranu), uz manju ili veću ranu, razderotinu, laceraciju prsnog koša, koja je neposredno najčešće i vidljiva.

\section{Nepenetrantna povreda srca}

Kod tupe traume dolazi do nagnječenja prsnog koša, srca, krvnih žila (ev. i drugih organa) od sile tupog udarca, a što se može dalje komplicirati strukturnim promjenama srca, perikarda, miokarda, srčanih valvula, korda tendineja, papilarnih mišića, rijetko endokarda te pluća, aortne stijenke s disekcijom i s arterijsko-venskim fistulama - nastalim npr. kod rupture sinusa Valsalve aorte $s$ lijevo-desnim shuntom ili lijevo-lijevim shuntom u LA te rijetko shuntom u perikardijsku vreću ili rupturom descendentne aorte na mjestu ligamentum arteriosum Botalli (posljednje zbog akceleracijskih i deceleracijskih sila oko osovine sigurnosnog pojasa u autu). U prvi trenutak djelovanja, blage tupe sile, unesrećeni može biti bez većih smetnji. Stoga, tupa trauma često zahtijeva duže kliničko praćenje i monitoriranje EKG-om, ultrazvukom srca, radiološkim i drugim metodama.

12-kanalni EKG treba snimiti odmah i najmanje 24 sata monitorirati te hospitalno promatrati bolesnika 7 dana i kod pretpostavljeno "lakših kontuzija" te potom činiti povremene kontrolne analize (holter EKG i ultrazvuk srca) koje mogu utvrditi (u kronicitetu) kasne promjene ${ }^{8,9}$. Tupu traumu blažeg intenziteta bolesnik nekad i zaboravi, pogotovo ako su prvi simptomi bili blagi — opća slabost i blaga substernalna is usually accompanied by an injury of other organ systems: lungs, pleura, mediastinum, trachea, bronchus, esophagus, ribs, aortic wall, spine, contributing to the occurrence of complex symptomatology and causing differential diagnostic difficulties ${ }^{1,3-5}$.

Reports of international trauma centers emphasize not only a need for direct emergency intervention "on the spot" but also the importance of timely awareness and preparedness of a surgical center team, which should allow for efficient inhospital intervention.

Despite direct assistance and emergency intervention on the spot of the incident, followed by the analysis and in-hospital treatment, traumatic injury of cardiac structures with pericardial tamponade still shows a high incidence of deaths in traffic accidents $-20 \%{ }^{6}$. There is a small number of interventions in case of penetrating cardiac injuries in surgical centers, only $0.5 \%$ of all surgical interventions ${ }^{5}$. It seems that many patients come late for professional specialist assistance, and the reason for this may be the fact that the emergency medical assistance in the field is not equipped with suitable apparatus or is unable to diagnose and provide an appropriate assistance. Cardiac traumas - both nonpenetrating and penetrating, in car accidents show a high common incidence from $80 \%$ to $90 \%{ }^{6,7}$. Non-penetrating injuries may not be immediately fatal, but the further follow-up often reveals complications followed by poor outcome thereby recording a high mortality over a longer post hospital period from $57 \%$ to $64 \% \%^{8}$.

\section{Definitions and causes}

Cardiac trauma is divided in:

- non-penetrating - blunt cardiac injury - without a direct visible injury (wounds, lacerations) in the chest, but later internal injury of the heart, aorta and any other organs can be indirectly determined;

- acute penetrating - sharp cardiac (wound) injury, with a smaller or larger wound, tear, chest laceration, which is directly usually visible.

\section{Non-penetrating cardiac injury}

In case of blunt trauma, contusions of the chest, heart, blood vessels (or any other organs) are caused by blunt force impact, which can further get complicated as a consequence of structural changes to the heart, pericardium, myocardium, heart valves, chordae tendineae, papillary muscles, rarely endocardium and lungs, aortic wall with dissection and arterial-venous fistulas - occurred for instance in case of sinus rupture of the Valsalva aorta with left-right shunt or left-left shunt in LA and rarely shunt in the pericardial sac or rupture of the descending aorta at the point of ligamentum arteriosum Botalli (the latter due to acceleration and deceleration forces around the seat belt shaft in the car). At the first moment of action of mild blunt force, the injured may feel no major problems. Therefore, blunt trauma often requires longer clinical follow-up and monitoring by ECG, echocardiography, radiological and other methods.

12-lead ECG should immediately record and should be monitoring a patient for at least 24 hours in the hospital even in case of presumed "minor contusions" to be followed by periodic follow-up analyses (Holter ECG and echocardiography), which can identify (in the chronicity) late changes ${ }^{8,9}$. Slight intensity blunt trauma will never be forgotten by a patient, especially if the first symptoms were mild - general fatigue and slight substernal pain. However, various 
bol. Međutim, u duljem su praćenju često prisutne različite aritmije, pa i ventrikulska tahikardija te smetnje provođenja s pogibeljnim AV blokovima ${ }^{10}$. Rijetke su manifestacije srčane slabosti s globalnim padom kontraktilnosti miokarda, ako nije bilo dokazanog opsežnijeg oštećenja.

Tamponada perikarda je vrlo rijetka u tupoj ozljedi, ali može ipak nastati djelovanjem nepenetrantne sile preko prsnog koša ili preko trbušne šupljine. Češće se javlja u situaciji tupe traume - manji perikardijski izljev s polaganim razvitkom, najčešće kao serozno eksudativna reakcija (ne hematoperikard), autoimunog uzroka nastanka. To su reakcije na minimalno oštećenje perikarda, poput postoperacijskog perikarditisa - perikardiotomički sindrom. Takav perikardijski izljev, obično manjeg volumena, ne ugrožava punjenje DV, a ako polagano dosegne veličinu oko $200 \mathrm{~mL}$ može kod bolesnika u naporu izazvati blagu tahikardiju i zaduhu. Povlačenjem eksudata mogu zaostati manje fibrinsko-fibrozne promjene unutar perikarda, bez značajnih hemodinamskiih implikacija (najčešće bez konstrikcije). Iznimno rijetko tupa trauma uzrokuje neposredno naglu smrt, kada kontuzija miokarda dovede do rupture miokarda zbog manje ili veće laceracije stijenke miokarda ili perikarda ili zbog opsežnije disekcije aortne stijenke ili kada se tupi udarac dogodi u tzv. vulnerabilnoj fazi srčane rezolucije.

lako je manje ugrožavajuća od penetrantne traume, jaka sila i kod takve ozljede može dovesti do oštećenja drugih organa, kao npr. do dijafragmalne hernije zbog nastale razderotine dijafragme s hernijacijom abdominalnog sadržaja u prsni koš i time učiniti pritisak -kompresiju na srčane šupljine, ali i hernijaciju miokarda kroz manju razderotinu perikarda, nastalu tupom silom ${ }^{4,8}$. Jaka tupa sila može preko prsnog koša i trbušne stijenke izazvati rotaciju srca i tzv. "luksaciju" čitavog srca iz njegovog sjedišta. Posljednje promjene treba isključiti u hospitalnom razdoblju, najbolje višeslojnom kompjutoriziranom tomografijom (MSCT).

Uzroci tupe nepenetrantne traume su mnogobrojni, češće samo s posljedičnim nagnječenjem prsnog koša i srca, a rjeđe manjim ili većim rupturama srca i okolnih organa. To se događa u prometnim nesrećama zbog nagle deceleracije, neposredne kontuzije volanom vozila u sternum te $u$ mnogobrojnim kontuzijama prsnog koša i trbuha kod prevrtanja vozila. Čest uzrok kontuzije prsnog koša i srca nadalje je pad s visine na tlo kao ozljeda na radu, namjerni jaki "ubilački" udarci rukom u prsni koš, nenamjerni jaki udarci loptom, sudar dvaju tijela u sportu, a u stočarstvu npr. udarac kopitom životinje u prsni koš, pad kod jahanja životinja, pad s motocikla, bicikla i sl. Kod liječničke reanimacije često se ne može izbjeći manje ili veće iatrogeno nagnječenje miokarda i perikarda, nekad i uz frakturu rebara (što može izazvati i penetrantnu ozljedu). Sljedeći uzroci su zračni udari — zračni "blast" u neposrednoj blizini eksplozije bombe, mine, s kompresijom sternuma i organa na kralježnicu, ev. vodeni "blast" ili druga kompresija toraksa između dviju nestlačivih - metalnih podloga.

Osim deceleracijskih sila kod zaustavljanja dvaju vozila, stvaraju se nekad u nesrećama i kod prevrtanja vozila i jake akceleracijske sile, velike snage, koje mogu dovesti do "fleksije" prsnog koša s manifestacijom sila rastezanja (stretching) i sila rotacije (twisting) 1 te time do ozljeda srca i drugih organa u prsištu. Učestale elektrokardioverzije mogu u terapijskim zahvatima biti uzrok mikropromjena na miokardu, edema miokarda, pa i manjih nekroza. Slično vrijedi i za nesretne udare izmjeničnom električnom strujom, a čini se i za udare elektriciteta iz munje (groma). U slučajevima tupe traume srca podatke o jačini miokardne ozljede može se arrhythmias, including ventricular tachycardia and conduction disorders with fatal AV blocks are usually present over a long follow-up period. ${ }^{10}$ Heart failure symptoms are rare with a global decrease in myocardial contractility, if no extensive injury has been proved.

Pericardial tamponade is very rare in the blunt injury, but still may be caused by non-penetrating forces through the chest or abdominal cavity. It occurs more commonly in a situation of blunt trauma - a smaller pericardial effusion with a slow development, usually as a serous exudative reaction (not hemopericardium) of autoimmune etiology. These are the reactions to minimal injury of the pericardium, such as postsurgical pericarditis - postpericardiotomy syndrome. Such a pericardial effusion, usually a smaller pericardial effusion, does not endanger the LV filling, and if it slowly reaches the size of approximately $200 \mathrm{~mL}$ it can cause mild tachycardia and dyspnea in the patient in effort. The retreat of exudates may lead to smaller fibrinous-fibrous changes that may remain within the pericardium, without significant hemodynamic implications (usually without constriction). Extremely rare blunt trauma causes a direct sudden death, when myocardial contusion causes myocardial rupture due to a minor or major laceration of the myocardial or pericardial wall due to a more extensive dissection of the aortic wall or when the blunt impact occurs in the so-called vulnerable stage of cardiac resolution.

Although it is less life-threatening than penetrating trauma, a strong force in case of such an injury may cause injury of other organs, such as diaphragmatic hernia as a result of diaphragmatic rupture with herniation of abdominal contents into the chest causing thus pressure on - compression of the cardiac cavities, but also myocardial herniation due to a small pericardial rupture, resulting from a blunt force ${ }^{4,8}$. A strong blunt force can cause rotation of the heart and the socalled "luxation" or the dislocation of the whole heart through the chest and abdominal wall. The last changes need to be excluded in the in-hospital period, best by using multi-layer computed tomography (MSCT).

The causes of blunt non-penetrating trauma are multiple, usually resulting in consequential chest and heart compression and rarely in minor or major ruptures of the heart and surrounding organs. This happens in car accidents as a result of sudden deceleration, direct contusion of the sternum by the steering wheel and numerous contusions of the chest and abdomen in case of a car rollover. A common cause of contusion of the chest and the heart is also a fall from the height onto the ground as an occupational injury, intentional strong "murderous" blows to the chest, unintentional fierce hit by the ball, collision of two bodies in the sport, and in cattle breeding the kick by an animal's hoof in the chest, falling off a riding animal, falling off a motorcycle, bicycle, etc. Minor or major iatrogenic myocardial and pericardial contusion cannot often be avoided in medical resuscitation, sometimes accompanied by fractured ribs (which can cause a penetrating injury). The following causes are air strikes - air "blast" in the immediate vicinity of the explosion of a bomb, mine, with compression of the sternum and organs on the spine, any water "blast" or other compression of the thorax between the two incompressible - metal substrates.

Besides the deceleration forces, when bringing two vehicles to a halt a strong acceleration forces are created, sometimes even in accidents in a case of rollover. Such acceleration forces of high power can lead to "flexion" of the chest with the manifestation of the stretching forces and twisting forces 1 and thus to the cardiac injury and injury of other organs in the chest. Frequent electrocardioversions can in therapeutic interventions be the cause of micro changes to the myocardium, myocardial edema and minor necrosis. The same applies to the unfortunate alternating electric current strikes, and probably to lightning strikes and electrical discharge produced by the thunderstorm. In cases of blunt 
dobiti određivanjem specifičnih miokardnih enzima i troponina.

\section{Akutna penetrantna povreda srca}

Kod akutne penetrantne - oštre ozljede posljedice djelovanja sila se očituju odmah teškim kardiološkim smetnjama i općim teškim stanjem ozlijeđenog, često s hipovolemičkim - uz oligemiju nemoragičnim šokom (neki kliničari hipovolemički šok nazivaju i "opstruktivnim" - jer je spriječeno normalno purijenje sica u dijasioli uz ev. opstrukciju velikih žila) ili opićenific traurratsikini šokrom, što zahtijeva što hitniju, podrobniju dijagnozu i terapiju. Uzroci takve ozljede s najčešće trenutnim smrtnim ishodom i u mirnodopskim su uvjetima i dalje projektili iz vatrenog oružja, zrna većeg kalibra iz samokresa/pištolja, "magnuma", "beretke" ili više manjih zrna iz oružja za lov "sačmarice"; namjerne ubodne rane hladnim oružjem, nožem; slučajne ozljede oruđem i drugim oštrim predmetima u industriji i proizvodnji. U prometnim nesrećama događaju se veće razderotine, laceracije prsnog koša i prekid kontinuiteta struktura perikarda, miokarda, aorte, oštrim rubovima frakturiranih rebara i sternuma, ozljedom "letećim" oštrim predmetima velikih brzina (akceleracijskih sila) od stakla ili lima te nekad i samim jakim kompresijama (s tlačenjem između sternuma, rebara i kralježnice). Procjenjuje se da je kod takvih događanja incidencija težih lacerirajućih oštećenja srca od oko $20 \%^{3}$, od kojih polovica završava smrtno. U poljoprivrednim aktivnostima svjedoci smo da je prevrtanje poljoprivrednih strojeva (traktora) gotovo uvijek smrtonosno za vozača. Radi li se pri tome o srčanoj smrti ili drugim uzrocima nije ispitano.

Penetrirajuća trauma srca u civilnom društvu sjeverne Amerike u četvrtini slučajeva (svih penetracija u prsa) i dalje je uzrokovana nožem. U Turskoj je retrospektivnom analizom od 2005. do 2008. god. pokazano da je 5\% penetrantnih ozljeda uzrokovano zrnom iz vatrenog oružja, a 95\% ubodnih rana hladnim oružjem, oruđem ili drugim ${ }^{11}$.

Premještaj (displasman) trbušnih organa u prsni koš i obratno (samog srca prema trbušnoj šupljini) preko rupturirane dijafragme dovodi do hernijacije trbušnih organa i nekad tzv. "luksacije", pomaka srca s nagnječenjem kao kod tupe traume ili/i s posljedičnom laceracijom, rupturom srca - miokarda, perikarda, disrupcijom srčanih valvula, papilarnih mišića, aorte i velikih vena. Ortopedski naziv "luksacija", "iščašenje", izvrnuće iz primarnog položaja srca, kao i "volvulus" (zapletaj) - naziv iz abdominalne hitne kirurgije ovdje iznimno imaju značenje zaokreta srca i velikih žila oko njihove osovine i mogu dovesti do opstrukcije vene kave inferior, velikih arterija i kompresije desne strane srca i medijastinalnih organa $^{1,12}$. Oštećenja su usko povezana i s kompliciranom srčanom rupturom u $28 \%$ slučajeva, čija smrtnost je visoka $67 \%{ }^{13}$. Značajna promjena električne osi na EKG-u u tim situacijama (ako je poznat raniji nalaz) suspektna je uvijek na "luksaciju" i premještaj srca.

I u penetrantnoj ozljedi uz laceraciju miokarda, perikarda, može istodobno postojati dodatno oštećenje miokardnih arterija, arteriola te preko ishemije dovesti do sekundarne nekroze i rupture miokarda ili opet neposredno zbog rupture stijenke koronarnih arterija i spomenutih arteriola do hematoperikarda.

Penetrirajuća, prostrijelna i ubodna rana vidljivo oštećuju prednji dio prsnog koša (najčešće na ulazu) te projektilom (nevidljivo) velike žile, aortu, vene, medijastinum i kralježnicu u kojoj se projektil može zaustaviti i prouzrokovati neurološke ispade. Projektil i ubodna rana mogu, međutim, biti cardiac trauma, the details on the severity of myocardial injury can be obtained by determining specific myocardial enzymes and troponin.

\section{Acute penetrating cardiac injury}

In acute penetrating - sharp injury the consequences of the forces are immediately manifested by severe cardiac disorders and severe general condition of the injured, often with hypovolemic - with oligemia, hemorrhagic shock (hypovolemic shock is called "obstructive shock" by some clinicians - because the normal filling of the heart in diastole with potential obstruction of large vessels is prevented) or generally with traumatic shock, which requires an urgent, thorough diagnosis and therapy. The causes of such an injury usually with a deadly outcome are even at peacetime still projectiles from firearms, larger caliber bullets from the rifle/pistol "magnum", "beret" or several smaller bullets from the hunting "shotgun"; deliberate stab wounds by cold weapon, knife; accidental injuries by tools and other sharp objects in the industry and production. In traffic accidents major tears, chest lacerations and a break in the continuity of the pericardial, myocardial, aorta structures which are caused by sharp edges of fractured ribs and sternum, an injury by "flying" high speed sharp objects (acceleration force) of glass or metal, and sometimes the very strong compressions (with compression between the sternum, ribs and spine) occur. It is estimated that the incidence of such events in severe cardiac lacerations is about $20 \%{ }^{3}$ of which a half of them end up with a fatal outcome. In agricultural activities, we have witnessed that overturning of agricultural machinery (tractors) is almost always fatal for a driver. It has not been studied whether a cardiac death or some other causes were the reason for death.

Penetrating cardiac trauma in the civil society of North America in a quarter of cases (of all penetrations into the chest) is still caused by a knife. In Turkey, a retrospective analysis conducted from 2005 to 2008 , showed that $5 \%$ of penetrating injuries were caused by bullets from a firearm, and $95 \%$ of stab wounds by a cold weapon, tools etc.11.

The displacement of abdominal organs in the chest and reversely (of the very heart towards the abdominal cavity) via the ruptured diaphragm leads to herniation of abdominal organs and sometimes the so called "luxation", displacement of the heart with contusion as in blunt trauma or/and with consequential laceration, rupture of the heart - myocardium, pericardium, disruption of cardiac valves, papillary muscles, aortic and large veins. Orthopedic term "luxation", "dislocation" from the primary position of the heart, as well as "volvulus" (obstruction) - the name taken from emergency abdominal surgery denote here rotation of the heart and large vessels around their axis and can lead to obstruction of the inferior vena cava, large arteries and compression of the right side of the heart and mediastinal organs ${ }^{1,12}$. The injuries are closely associated with complicated cardiac rupture in $28 \%$ of cases, where mortality is high $-67 \%{ }^{13}$. Significant changes in the electrical axis in ECG in these situations (if an earlier finding is known) are always suspicious for "luxation" and "dislocation" of the heart.

The penetrating injury along with the myocardial, pericardial laceration can be accompanied by additional injury of myocardial arteries and arterioles causing secondary necrosis and myocardial rupture through ischemia or again directly causing hemopericardium as a consequence of the rupture of the walls of coronary arteries and above mentioned arterioles.

The penetrating, gunshot and stab wounds visibly damage the anterior chest (usually at the entrance) and the missile (invisibly) damage large vessels, aorta, veins, mediastinum, and spine where the missile can stop and cause neurological injuries. The missile and stab wounds, however, can be 
usmjereni iz trbušne šupljine u pravcu srca, pa je tada ulazna rana na trbušnoj stijenci, ponekad i sa stražnje strane prsišta u leđima, što zahtijeva detaljan pregled da se rane ne previde. Lacerirajuća povreda srca može se dogoditi i iznutra kod jakih kompresija (bez vidljive ulazne i izlazne rane) te kod nekih dijagnostičkih i terapijskih kardioloških zahvata kao što su: kateterizacije srca, ispitivanja provodnog sustava srca, radiofrekventne ablacije provodnih puteva, postavljanja električnog stimulatora srca, TAVI operacije aortne srčane greške ili rekonstrukcije zalistka arterijskim ili venskim putem (kao npr. kod perkutane mitralne valvuloplastike, plastike trikuspidnog zalistka), biopsije miokarda, za vrijeme koronarografije s postavljanjem stentova ili/i tijekom dilatacije koronarnih arterija.

\section{Patofiziologija i klinička slika tamponade perikarda}

Svaki perikardijski sadržaj uz nastalu akutnu oštru traumu srca treba smatrati hematoperikardom dok se ne dokaže suprotno, kao i potencijalnim uzrokom tamponade perikar$\mathrm{da}^{1,3,9,11,24}$. Hematoperikard zbog naglog nastanka i ovdje velike količine krvi u perikardijskoj šupljini bez intervencije gotovo uvijek prelazi u tamponadu. Stoga intervenciju, terapijsku perikardiocentezu, treba učiniti što prije, u intervenciji ekipe hitne medicinske pomoći (HMP) na terenu incidenta, osim kod ozbiljne sumnje da je hematoperikard uzrokovan disekcijom aorte, kada je perikardiocenteza kontraindicirana.

Tamponada perikarda se ujedno smatra i ekvivalentom ponajprije penetrantne ozljede srca izvana (iako može nastati i kod nepenetrantne ozljede) koja ne mora biti vidljiva kao rana na površini prsnog koša ili trbuha. Statistički podaci ukazuju da neke ubodne rane hladnim oružjem, uskim vrškom noža ili manje ubodne rane vrškom frakturiranog rebra, ivera sternuma imaju bolju prognozu od rana nastalih vatrenim oružjem. Nastanak tamponade perikarda u prvom slučaju je obično postupniji, polaganiji, a mala rana ili rana uzdužnog rasjeka miokarda i perikarda nekada se stisne, suzi te može i spontano trombozirati. Oštećenje miokarda velikim projektilom dovodi naglo do tamponade velikom količinom hemoperikarda, a ukoliko nema intervencije, često i do brzog smrtnog ishoda.

Na procjeni količine perikardijskog sadržaja neposredno nakon incidenta već su 1999. god. inzistirali japanski autori primjenom ultrazvuka srca i intervencijom ${ }^{9}$. Perikard nije rastezljiv, osim u postupnom povećanju perikardijskog sadržaja (hipotireoza, uremija) kada se može povećati volumen perikardijske vreće sve do 1.500-2.000 mL, bez značajnih simptoma u mirovanju. Ako se perikardijski sadržaj poveća naglo, nekad i 100mL krvi može uzrokovati simptome tamponade.

Naglim povećanjem volumena u perikardijskoj vreći raste intraperikardijski tlak. Kada se tlak u perikardu približi tlaku u DA, funkcija DV je bitno oštećena. Povišeni intraperikardijski tlak ometa nadalje dijastoličko širenje klijetki. To vodi daljem povećanju intrakavitarnog dijastoličkog tlaka i smanjuje punjenje klijetke (u početku više DV, potom i LV), a time se bitno smanjuju udarni i minutni volumen lijeve strane srca i pada sustavni arterijski tlak. Porast intraperikardijskog tlaka je u upravnoj korelaciji i s porastom sustavnog venskog tlaka i tlaka u plućnim venama te posljedično dovodi do spomenutog porasta tlaka u DA, ali i u LA. Zbog porasta sustavnog venskog tlaka i tlaka u plućnim venama, dijastoličkog tlaka u obje komore, dijastoličkog tlaka i u plućnoj directed from the abdominal cavity in direction of the heart, and then the entry wound in the abdominal wall is sometimes in the posterior chest in the back, which requires a detailed examination to prevent overlooking of the wound. Cardiac laceration can even occur from the inside in case of strong compressions (with no visible entry and exit wound) and in some diagnostic and therapeutic cardiac procedures such as: cardiac catheterization, examining the conduction system of the heart, radiofrequency ablation of conductive pathways, implantation of electrical pacemaker, TAVI procedures on the aortic heart valve defects or arterial or venous valve repair (such as in percutaneous mitral valvuloplasty, plastic procedure on the tricuspid valve), myocardial biopsy, during coronary angiography with stent implantation and/or during the dilation of coronary arteries.

\section{Pathophysiology and clinical course of pericardial tamponade}

Each pericardial fluid with sharp cardiac trauma should be considered hemopericardium unless proven otherwise, and also the potential cause of pericardial tamponade ${ }^{1,3,9,11,24}$. Due to its sudden occurrence and here large amounts of blood in the pericardial cavity, hemopericardium develops almost always to tamponade if no intervention is performed. Therefore, the intervention, therapeutic pericardiocentesis should be performed as soon as possible by the emergency medical services (EMS) on the spot of the incident, except in case when reasonably suspecting that hemopericardium is caused by aortic dissection, when pericardiocentesis is contraindicated.

Pericardial tamponade is also considered equivalent primarily to penetrating cardiac injury from the outside (although it can occur in case of non-penetrating injury) that may not be visible as a wound on the surface of the chest or abdomen. The statistical data show that some stab wounds caused by cold weapons, a narrow tip of a knife or minor stab wounds caused by a tip of a fractured rib, body of sternum have a better prognosis than the gunshot wounds. The pericardial tamponade in the first case usually occurs more gradually, slowly, and a minor wound or a longitudinal myocardial or pericardial rupture wound is sometimes squeezed, narrowed and can spontaneously thrombosed. Myocardial injury by a large missile causes a sudden tamponade by a large amount of hemopericardium, and a fatal outcome if no intervention is performed.

The Japanese authors insisted on the assessment of the amount of pericardial fluid immediately after the incident in 1999 by using the heart ultrasound and intervention ${ }^{9}$. Pericardium may not stretch, except in gradual increase in pericardial fluid (hypothyroidism, uremia) when the volume of pericardial sac can increase up to $1,500-2,000 \mathrm{~mL}$ without significant symptoms at rest. If the pericardial fluid increases all of a sudden, sometimes $100 \mathrm{~mL}$ of blood, can cause symptoms of tamponade.

A sudden increase in volume in pericardial sac increases intrapericardial pressure. When the pressure in the pericardium becomes close to the pressure in the RA, RV function is then significantly impaired. Elevated intrapericardial pressure hinders further ventricular diastolic expansion. This leads to a further elevation of intracavitary diastolic pressure and reduces ventricular filling (initially more $\mathrm{RV}$, followed by LV), thus significantly reducing the stroke and minute volume of the left side of the heart whereas the systemic arterial pressure drops. The elevation of the intrapericardial pressure administratively correlates to an elevation of the systemic venous pressure and the pressure in the pulmonary veins consequently leading to the aforementioned elevation of pressure not only in the RA, but also in LA. The elevated systemic venous pressure and pulmonary venous pressure, 
arteriji, rastu vrijednosti tlaka u srcu na približno istu razinu: nestaju intrakavitarne i intravaskularne razlike tlaka i nastaje stanje tamponade perikarda s daljnjim padom udarnog volumena, padom arterijskog tlaka i preko cirkulacijskog kolapsa dolazi do kardiogenog šoka, najčešće sa smrtnim ishodom.

Može se zaključiti da tamponadu perikarda patofiziološki karakterizira:

1. povećanje intrakardijskih tlakova uzrokovano naglim povećanjem intraperikardijskog tlaka,

2. ograničeno punjenje srčanih komora u dijastoli,

3. redukcija udarnog i minutnog volumena srca.

Kliničku simptomatologiju tamponade čini u početku jaka prsna bol substernalno te epigastrično (vezana najčešće uz lacerirajuću ozljedu), potom opće teško prostrirajuće stanje s bljedoćom, zaduhom, tahipnejom, tahikardijom, a ponekad u početku i disfagijom, kašljem, promuklošću zbog često jake kompresije pluća, bronha i rekurentnog živca. Na kraju dominira slika šoka.

Fizikalnim pregledom se utvrde tipični znakovi tamponade:

1. sustavna hipotenzija (mali udarni i minutni volumen);

2. distenzija jugularnih vena kao znak nemogućnosti punjenja DV i povišenja tlaka u desnom dijelu srca i venskom sustavu;

3. mukli ili nečujni srčani tonovi (uz tahikardiju) - sve nazvano karakterističnim Beckovim trijasom ${ }^{14}$.

Gotovo je uvijek prisutna spomenuta tahikardija zbog kompenzatorne simpatikotonije i kateholaminemije, kao reakcija na pad udarnog volumena i doživljenu traumu; tahipneja (kompresija pluća, bronha, hipoksija), blijedoća kože i sluznica te ev. periferna cijanoza. Perikardijsko trenje kod većeg se izljeva ne čuje. Veći hematoperikard komprimira lijevo plućno krilo, što se perkutorno očituje muklinom, a auskultatorno nečujnim disanjem (Ewartov znak). Inače nema fizikalnih znakova zastoja u plućima što je karakteristično. Arterijski tlak je nizak — oko ili ispod $90 \mathrm{mmHg}$. Kada bi se mjerio venski tlak u kubitalnoj veni, bio bi povišen.

Može biti prisutan tipičan Kussmaulov znak, koji se očituje smanjenjem distenzije vratnih vena u inspiriju (a koji nije izražen u težoj hipovolemiji) te karakterističan tzv. paradoksni nalaz pulsa, ev. uz pad tlaka. Paradoksni puls je usporenje frekvencije srca u inspiriju (normalno je ubrzanje), a što se teško može klinički ocijeniti u prisutnoj tahipneji. Arterijski tlak mjeren u inspiriju trebao bi pasti također za 15-20 mmHg da se znak prihvati pozitivnim za tamponadu (što neki kliničari također svrstavaju u paradoksnost). Pad tlaka u inspiriju je inače normalno prisutan u zdravih individua ali i u nekim drugim bolestima, pa se sensu stricto ne može taj pad nazvati visoko specifičnim paradoksnim znakom.

Smanjenje distenzije jugularnih vena u inspiriju je znak kratkotrajnog sniženja tlaka u DA i intraperikardijski zbog kratkotrajno nastalog negativnog tlaka u prsnom košu. To omogućuje samo kratkotrajno punjenje DV i kratkotrajno povećanje dimenzija kaviteta DV u inspiriju.

Za tamponadu i oštećenje perikarda nema patognomoničnog EKG znaka, ali se ponekad može utvrditi više značajnih: 1. elevacija ST-spojnice, na vrhu tipično konkavna; 2. električni alternans; 3. niska voltaža amplituda QRS-kompleksa (zbroj amplituda u D1, D2, D3 manje od $15 \mathrm{~mm}$ ). Posljednji je također neosjetljiv i nespecifičan znak tzv. "kratkog spoja" u putovanju električnog impulsa kroz perikardijski izljev, jer diastolic blood in the both chambers, diastolic pressure in the pulmonary artery lead to an elevation of pressure values in the heart at approximately the same level: intracavitary and intravascular pressure differences disappear resulting in the condition of pericardial tamponade with a further drop in stroke volume, drop in blood pressure and via circulatory collapse causing cardiogenic shock, often with a fatal outcome.

It can be concluded that pericardial tamponade is pathophysiologically characterized by:

1. elevation of intracardiac pressures caused by sudden elevation of intrapericardial pressure;

2. limited diastolic filling of cardiac chambers;

3. reduction of cardiac stroke and minute volume.

Clinical symptomatology of tamponade is at first manifested as a strong substernal and epigastric chest pain (usually associated with laceration-related injury), followed by the general serious prostrate condition with pallor, dyspnea, tachypnea, tachycardia, and sometimes at the beginning with dysphagia, cough, hoarseness due to frequently severe compression of the lungs, bronchus and recurrent nerve. The manifestation of shock is finally dominant.

Physical examination determines the typical signs of tamponade:

1. systemic hypotension (low stroke and minute volume);

2. jugular vein distension as a sign of a failure of filling $R V$ and rise in pressure in the right side of the heart and venous system,

3. a muffled or inaudible heart sounds (with tachycardia) all called as characteristic Beck's triad ${ }^{14}$.

Tachycardia is almost always present due to compensatory sympathicotonia and catecholamine, in response to the fall in stroke volume and history of trauma: tachypnea (compression of the lungs, bronchi, hypoxia), paleness of skin and mucous membranes, and potential peripheral cyanosis. Pericardial friction is not heard in major effusion. Larger hemopericardium compresses the left pulmonary lobe, which is reflected by dullness to percussion and inaudible breathing auscultatory (Ewart's sign). Otherwise, there are no physical signs of delays in the lungs which is a typical phenomenon. Arterial pressure is low - around or below 90 $\mathrm{mmHg}$. When venous pressure in cubital vein was measured, it would be elevated.

A typical Kussmaul's sign may be present. It is reflected by reducing neck vein distension in inspiration (which is not expressed as more severe hypovolemia) and characteristic paradoxical pulse finding, accompanied by a potential pressure drop. Paradoxical pulse is a slowdown of the heart rate in the inspiration (acceleration is normal), which is difficult to assess clinically in presence of tachypnea. Blood pressure measured in the inspiration should also drop to $15-20 \mathrm{mmHg}$ in order to accept the sign as positive for tamponade (which is classified as paradox by some clinicians). The drop in pressure in the inspiration is otherwise normally present in healthy individuals, but also in other diseases, so sensu stricto this drop can not be called a highly specific paradoxical sign.

Reduction of jugular vein distension in the inspiration is a sign of a short-term drop in pressure in RA and intrapericardially as a result of a negative pressure in the chest. This allows only a slow filling of RV and transitory increase in cavity size of RV in the inspiration.

For pericardial tamponade and injury there is no pathognomonic ECG sign, but sometimes several significant ones can be determined: 1 . elevation of the ST-segment at the top typically concave; 2 . electrical alternans; 3 . low voltage of amplitude of QRS-complex (the sum of the amplitudes in D1, D2, D3 less than $15 \mathrm{~mm}$ ). The latter is also an insensitive and a nonspecific sign of the so-called "short circuit" in the electrical impulse travel through the pericardial effusion, 
postoji i u pretilosti, u pleuralnom izljevu lijevo, nekim kardiomiopatijama, amiloidozi... $)^{15,16}$.

Jak porast intraperikardijskog tlaka u tamponadi oštećuje i smanjuje protok u subendokardnom i subepikardnom dijelu miokarda uzrokujući time miokardnu ishemiju, koja se može očitovati u zapisu 12-kanalnog EKG-a kao konveksna elevacija ST-spojnice s pozitivnim ili negativnim T-valom. Depresija ST-spojnice je iznimna. Opisani nalaz ST-spojnice na EKG-u u tamponadi je također nespecifičan. Vrlo su rijetki q- ili QS-zupci i također nisu izraz perikardnog oštećenja u tamponadi, nego subepikardnog oštećenja miokarda, jer i elektrofiziološki visceralni i parijetalni list perikarda i inače normalno ne stvaraju nikakvu razliku električnog potencijala zbog male mase perikarda, da bi je se moglo uopće registrirati ${ }^{15}$. Ruptura miokarda uz tamponadu, ovisno o veličini, može dati sliku nekroze s q- ili QS-zupcima. Razumljivo je, stoga, da i laboratorijski nalazi specifičnih miokardnih enzima i troponina ukazuju samo na dodatno oštećenje miokarda, a ne perikarda, ${ }^{5,15}$.

Prilikom ehokardiografskog pregleda u tamponadi mogu se utvrditi sljedeći znakovi:

1. povećanje DV u inspiriju s recipročnim smanjenjem LV;

2. kolaps DA u ekspiriju;

3. kolaps DA u sistoli duže od trećine trajanja sistole (osjetljivost $90 \%$, specifičnost $100 \%$ );

4. dijastolički kolaps DA i ev. LA, a vrlo rijetko LV;

5. paradoksni pomak iv. septuma u inspiriju prema LV;

6. kolaps DV neposredno nakon zatvaranja pulmonalnog zalistka i otvaranja trikuspidnog, dakle, u ranoj dijastoli;

7. suženje - kolaps izgonskog trakta DV, eksperimentalno osjetljiviji znak čak od kolapsa DV

8. distenzija - dilatacija vene kave inferior (subkostalnim pristupom) bez smanjenja za 50\% u inspiriju (što upućuje na povećani srednji tlak u DA iznad $10 \mathrm{mmHg}$ );

9. povećanje protoka u inspiriju, mjereno Doppler metodom, kroz trikuspidno ušće, a smanjenje protoka u inspiriju kroz mitralno ušće i obratno u ekspiriju

10. pristupom transtorakalno-supraklavikulano (iz juguluma) može se utvrditi stanje arkusa aorte, asc. aorte i proksimalnog dijela desc. aorte te s izvjesnom sigurnošću dokazati ili isključiti disekciju aortne stijenke kao mogući uzrok tamponade ${ }^{17}$.

\section{Patomorfologija i klinička slika kontuzije miokarda}

Kontuzija miokarda (nagnječenje od udarca) je u većini slučajeva ekvivalent tupe, nepenetrantne traume srca povezane s tupom traumom prsnog koša (ponekad i tupom traumom trbuha $)^{1,4,8}$. Ova trauma srca ovisi o snazi "tupih" sila u djelovanju na prsni koš, ponajprije o učinku tzv. akceleracijskih sila koje djeluju ne samo na površinu prsnog koša, nego time i na površinu srca te na površinu i unutrašnjih srčanih struktura i drugih organa u prsnom košu. Učinak ovisi o mjestu udara, rastežljivosti prsnog koša (dječji ima povećanu rastežljivost, pa je manje smrtnih slučajeva u prometu) i o fazi srčane rezolucije u kojoj se dogodio udarac. Dokazano je na animalnim modelima da nekad i manja sila u kritičnoj fazi srčane rezolucije može izazvati naglu smrt ${ }^{15,18}$. Nema danas standardnih parametara za točnu procjenu veličine, jačine sile i snage tupe traume kod ljudi koja dovodi do kontuzijskog oštećenja, što je razumljivo. Kritičnu fazu srčane rezolucije kod ljudi također je gotovo nemoguće as it is even present in obesity in the left pleural effusion, some cardiomyopathies, amyloidosis ... $)^{15,16}$.

A strong elevation of intrapericardial pressure in the tamponade damages and reduces the flow in the subendocardial and subepicardial part of the myocardium causing thus the myocardial ischemia, which can be manifested in a record of 12-lead ECG as convex elevation of the ST-segment with the positive or negative T-wave. The depression of the STsegment is exceptional. The described finding of the STsegment on ECG in the tamponade is also nonspecific. $Q$ or QS waves are very rare and are also not the sign of the pericardial tamponade, but of subendocardial myocardial injury, because the electrophysiological visceral and parietal layer of the pericardium normally make no difference in the electric potential due to a small pericardial mass, so that it could be recorded at all ${ }^{15}$. Myocardial rupture with tamponade, depending on size, can give an image of necrosis with $\mathrm{Q}$-or QS-wave. It is understandable, therefore, that laboratory findings of specific myocardial enzymes and troponin just additionally indicate the injury of the myocardium, not of pericardium ${ }^{5,15}$.

When making echocardiographic examination of tamponade the following signs can be determined:

1. elevation of $\mathrm{RV}$ in the inspiration with reciprocal reduction in LV;

2. collapse of RA in the expiration;

3. RA collapse in systole longer than a third of the systole duration (sensitivity $90 \%$, specificity 100\%);

4. diastolic collapse of RA and potentially LA, very rarely LV; 5. paradoxal shift of iv. septum in the inspiration towards LV; 6. collapse of RV immediately after the closure of pulmonary valve and opening of tricuspid valve, that is, in early diastole; 7. constriction - RV outflow tract collapse, experimentally a sign even more sensitive than the RV collapse

8. distension - inferior vena cava dilatation (by subcostal approach) without reduction by $50 \%$ in the inspiration (which indicates an elevated medial pressure in RA above $10 \mathrm{mmHg}$ );

9. an increase in the flow in the inspiration, measured by Doppler method, through the tricuspid orifice, and a decrease in flow in the inspiration through the mitral orifice and reversely in the expiration

10. by transthoracic-supraclavicular approach (from the jugulum) we can determine the condition of aortic arch, ascending aorta and proximal part of descending aorta and can with a certainty prove or exclude the dissection of aortic wall as a possible cause of tamponade ${ }^{17}$.

\section{Pathomorfology and clinical course of myocardial contusion}

Myocardial contusion (contusion caused by a blow) is in most cases equivalent to blunt, non-penetrating cardiac trauma associated with blunt chest trauma (sometimes even by blunt abdominal trauma $)^{1,4,8}$. The cardiac trauma depends on the strength of "blunt" forces exerted on the chest, primarily on the effect of the so-called acceleration forces exerted not only on the surface of the chest, but consequently also on the surface of the heart and on the surface of internal cardiac structures and other organs in the chest. The effect depends on the site of impact, compliance of the chest (children's chest has increased compliance, so there is fewer number of fatalities in car accidents) and the stage of cardiac resolution in which the impact occurred. It has been proved on animal models that sometimes less force at a critical stage of the cardiac resolution can cause a sudden death $^{15,18}$. Today there are no standard parameters for an accurate assessment of the size, strength of force and power of blunt trauma in people that leads to contusion, which is understandable. The critical stage of the cardiac resolution 
odrediti, jer nitko ne nosi holter EKG-aparat u fazi doživljene sile. Ostaje kao jedina točnija procjena snage sile tupe miokardne traume prema histološkom nalazu na autopsiji.

Patomorfološke promjene mogu se histološki utvrditi u obliku blagog edema tkiva miokarda, intramuralne hemoragije, manje ili veće nekroze miokarda koju može slijediti ruptura stijenke ${ }^{1,4,6,14}$. Ruptura miokarda kod tupe traume srca javlja se u oko 0,3\%-1,1\% (neposredno) traumatiziranih. U duljem promatranju posttraumatskog stanja, nekad i mjesecima ili godinama, događaju se i smrtni ishodi. Mislimo da je teško dokazati uzročnu povezanost nakon dužeg vremena od traume pa je moguće da u studijama (koje navode visoku posthospitalnu smrtnost) nisu dovoljno isključeni svi drugi uzročni faktori?

Pneumoperikard se može javiti poslije tupe traume, komplicirane rupturom, laceracijom perikarda i okolnog plućnog tkiva (dokazuje se MSCT pretragom prsnog koša). Oštećenja koronarnih arterija u tupoj se traumi događaju u oko $2 \%$ i to najčešće lijeva prednja silazna aterija, ali i desna koronarna arterija koja je lacerirana desno iza sternuma, dok je cirkumfleksna arterija zahvaćena vrlo rijetko ${ }^{19-21}$. Višežilna koronarna oštećenja su rijetka. Traumatska valvularna disfunkcija s nastankom plućnog edema je također rjeđa ${ }^{6}$. Najčešće je oštećena aortna valvula, slijede mitralna i trikuspidna. Mehanizam nastanka disrupcija kuspisa je nagli porast intrakardijalnog tlaka kod zatvaranja valvule. Uzroci valvularne disfunkcije su rastrgnuće ili izvrnuće, otrgnuće (avulzija) anulusa i najčešće nekoronarnog aortnog kuspisa ${ }^{6}$.

Već sam edem miokarda može kompromitirati koronarnu cirkulaciju kompresijom pa se razvije ("sekundarna") ishemi$\mathrm{ja}^{4,18}$. S obzirom da se proces djelovanja tupe sile događa pretežno u miokardu, razumljivo je da se elektrokardiografski može manifestirati kao ishemija ili češće kao infarkt miokarda, koji ima ponekad i zupce nekroze q- ili QS. ST-spojnica u takvim oštećenjima obično je elevirana s konveksitetom na vrhu (kao u infarkta), a T-valovi češće su odmah negativni. ST-spojnica može u nekim odvodima biti i jače denivelirana. Važno je istaknuti da neposredno učinjen EKG s patološkim promjenama identificira rizičnog bolesnika, ali normalan nalaz EKG-a neposredno nakon incidenta nije od pomoći, jer mu je vrijednost negativno prediktivna. Neposredno nakon incidenta, ako je kontuzijska sila bila jaka mogu se utvrditi učestale srčane aritmije u oko $28 \%$ tupih ozljeda ${ }^{8}$ uz smetnje provođenja. Obično se radi o neopasnim ekstrasistolama, supraventrikulskim tahikardijama, atrijskim ekstrasistolama. Čest je blok desne grane koji u lakšoj ozljedi i nestaje unutar 24 sata, a blok lijeve grane je rijedak. Javljaju se i ventrikulske ekstrasistole i ventrikulska tahikardija, slično kao u ranom postinfarktnom razdoblju, koja kod manjih oštećenja dobro reagira na medikamentnu terapiju (amiodaronom, a rijetko je potrebno dati alternativni lijek lidokain $100+50 \mathrm{mg}$ ).

Međutim, ne smije biti iznenađenja za ekipu HMP jer se u ranom razdoblju poslije teške kontuzije javlja i postojana ventrikulska tahikardija (bez pulsa) pa i fibrilacija ventrikula (ritmovi koji se defibriliraju), a koji se javljaju uz srčani arest te se trebaju intenzivno liječiti prema novim smjernicama ${ }^{22,23}$. Nakon tri početne defibrilacije bez uspjeha, preporuča se ordinirati adrenalin $1 \mathrm{mg}$ i.v. (ili intraosealno: humerus, tibia) i ponavljati ga svakih 3-5 minuta. Javlja li se ponovljeno fibrilacija ventrikula treba ordinirati amiodaron $300 \mathrm{mg}$ i.v. u $5 \%$ glukozi u bolusu te ev. dodatno još $150 \mathrm{mg}$ amiodarona.

Često se ipak dogodi neuspjeh te se javlja asistolija — stanje bez električne ventrikulske aktivnosti, iako električna ak- in people is also almost impossible to determine because no one wears Holter ECG monitor in the stage of experienced force. The only accurate assessment of strength of myocardial blunt force trauma force can be made according to the histological findings at autopsy.

Pathomorphological changes can be histologically determined in the form of mild edema of the myocardial tissue, intramural hemorrhage, minor or major myocardial necrosis, which may be followed by rupture of the wall ${ }^{1,4,6,14}$. Myocardial rupture in blunt cardiac trauma occurs in approximately $0.3 \%$ $1.1 \%$ of (directly) traumatized persons. Deadly outcomes occur in a longer observation of post-traumatic condition, sometimes lasting for months or years. We think it is difficult to prove a causal connection after a long time since the period of trauma, so it is possible that studies (indicating a high post-hospital mortality) do not sufficiently exclude all other causal factors.

Pneumopericardium may occur after the blunt trauma, being complicated by rupture, laceration of the pericardium and surrounding lung tissue (as proved by MSCT examination of the chest). Damage to the coronary arteries in blunt trauma occurs in about $2 \%$, mostly it is the left anterior descending artery and the right coronary artery which is lacerated on the right side behind the sternum, while the circumflex artery is rarely affected ${ }^{19-21}$. Multi-vessel coronary injuries are rare. Traumatic valvular dysfunction with the development of pulmonary edema is also more rare ${ }^{6}$. Aortic valve, followed by mitral and tricuspid valve are mostly damaged. The mechanism of development of cusp disruptions is a sudden elevation of intracardial pressure when closing the valve. The causes of valvular dysfunction are tear or distortion, avulsion of annulus and usually of non-coronary aortic cusp ${ }^{6}$.

The myocardial edema itself may compromise the coronary circulation by compression resulting in the development of ("secondary") ischemia ${ }^{4,18}$. Since the process of exerting blunt force mainly occurs in the myocardium, it is understandable that it can be manifested as ischemia by electrocardiographic leads, or more often as myocardial infarction, whereas q or QS waves sometimes suggest necrosis. The ST-segment in such injuries is usually elevated with the convexity on the top (as in the infarction), and T-waves are often immediately negative. The ST-segment may in some leads be even more denivelated. It is important to point out that recently performed ECG with pathological changes identify a patient at risk, but the normal finding of ECG taken immediately after the incident is of no help, because its value is negatively predictable. Immediately after the incident, if the contusion force was strong, frequent cardiac arrhythmias in around $28 \%$ of blunt injuries ${ }^{8}$ with the conduction disturbance can be determined. Usually, these are harmless extrasystoles, supraventricular tachycardia, atrial estrasystoles that are concerned. The right bundle branch block which in case of minor injury disappears within 24 hours, while the left bundle branch block is rare. Ventricular extrasystoles and ventricular tachycardia also occur, similar to the early postinfarction period, which in case of minor injuries are well treated by medicamentous therapy (amiodarone, and an alternative medicine - lidocaine $100+50 \mathrm{mg}$ is rarely to be administered).

However, the EMS team should be not surprised, because the early period after the severe contusion is followed by the sustained ventricular tachycardia (pulseless), including ventricular fibrillation (rhythms that are defibrillated), which occur along with cardiac arrest and they should be treated intensively according to the new guidelines ${ }^{22,23}$. After three initial defibrillations without success, it is recommended to prescribe epinephrine $1 \mathrm{mg}$ i.v. (or intraoseal: humerus, tibia) which is to be repeated every 3-5 minutes. If the ventricular fibrillation reoccurs, amiodarone $300 \mathrm{mg}$ i.v. in $5 \%$ glucose in bolus and additionally $150 \mathrm{mg}$ amiodarone should be prescribed. 
tivnost može postojati u vidu P-valova koji nisu uvijek vidljivi na EKG-u. Potrebno je ponovno procjeniti spoj elektroda i ocijeniti nalaz EKG-a. Može postojati asistolija i kod sumnje da se radi pretpostavljeno o tzv. "finoj fibrilaciji ventrikula" (nevidljivoj u EKG zapisu) te se donedavno i u toj situaciji nastavljalo s defibrilacijom. Današnji je stav da se kod asistolije sumnjive na "finu" fibrilaciju ventrikula ne čini ponovo defibrilacija?! Ritmovi koji se ne defibriliraju su dokazana (agonalna) prava asistolija i električna aktivnost bez pulsa (PEA), često zvana elektromehanička disocijacija. Kod asistolije ili razvoja bloka može se pokušati s perkutanom stimulacijom, primjenom torakalnih elektroda ili dakako aplikacijom sa spomenutim adrenalinom. Nove preporuke smatraju da primjena atropina od $3 \mathrm{mg} \mathrm{u}$ bolusu nije od velikog učinka (iako ga i nadalje primjenjujemo u pojedinim situacijama kao potentnog vagolitika).

Prema novim stavovima Europskog društva za resuscitaciju $u^{22,23}$, objavljenim 2010. godine, preživljavanje nakon kardijalnog aresta s asistolijom ili električnom aktivnosti bez pulsa je malo vjerojatno, ako se odmah ne otkriju i ne riješe uzroci (kao što je to ovdje tamponada perikarda). Kod prave asistolije nema koristi od električne stimulacije konsensus je stručnjaka na internacionalnoj razini.

U kontuzijskim oštećenjima srca nisu se smatrale potrebnim druge hospitalne mjere, poput privremenog uvođenja hipotermije $32-34^{\circ} \mathrm{C}$, ako bolesnik poslije kardijalnog aresta srca nije bio u komi i nema neurološke ispade. Sadašnja preporuka je da se stanje poslije kardijalnog aresta tretira i hipotermijom. Vrlo je rijetko potrebna mehanička ventilacija uz miorelaksanse i sedaciju, a ekstremno rijetko primjena danas moderne mehaničke potpore srčanožilnom sustavu aparaturom VAD, BIVAD, LVAD, RVAD, LVAS - HEART MTTE II ili dr.

Sva simptomatologija i klinički status ovise o veličini oštećene miokardne mase, koja će dovesti do asistolije i nepopravljivog kardijalnog aresta. Uništenje $>50 \%$ miokardne mase je vrlo rizično ${ }^{24}$. U kontuzijama prsnog koša više je izvrgnut oštećenju DV, a masa njegova miokarda je manja od mase LV, pa i porast miokradnih specifičnih enzima i troponina, usprkos jakoj sili može stoga biti blag što ne pridonosi ocjeni težine kliničke slike ${ }^{5}$.

Tupa trauma prsnog koša s kontuzijom miokarda je statistički češća od penetrantne ozljede, ali čini se da je neposredno za život manje opasna. Cesto se postavlja pitanje nagle smrti sportaša koji su doživjeli mnoge manje ili veće tupe traume prsnog koša, npr. nogometaša (padovi, sudari, udarci loptom u prsa i sl.), a koji su praktički svi bili prije kardiološki pregledani i nisu imali dokazane uobičajene uzroke nagle srčane smrti. Malobrojno snimani EKG kod kolapsa, odnosno sinkopa nogometaša na terenu ipak ukazuju na malignu ventrikulsku tahikardiju, možda vezanu uz ranije tupe traume? Ako se poslije tupe traume prsnog koša razvije rezistentna hipotenzija usprkos adekvatnoj resuscitaciji hipovolemije i ako nije prisutan drugi evidentni uzrok stanja, treba napraviti dodatnu koronarografiju ${ }^{21}$.

\section{Ostale hitne intervencije kod traume srca}

Dijagnozu traume srca, osobito penetrantne, trebalo bi utvrditi što prije poslije doživjelog incidenta, jer hitna intervencija kod sumnje na razvitak tamponade perikarda može spasiti život unesrećenika i uvjet je za uspješnu reanimaciju, ako se dogodi kardijalni arest. Očevidna rana, razderotina
However, a failure often occurs, whereas asystole occurs the state without electrical ventricular activities, although electrical activity may exist in the form of $P$-waves which are not always visible in the ECG. It is necessary to re-evaluate the connection of electrodes and evaluate the ECG findings. Asystole may exist when suspecting that the so called "fine ventricular fibrillation" (invisible in the ECG record) is concerned and until recently defibrillation continued to be performed in this situation. The today's attitude is that no repeated defibrillation should be performed in case of asystole susceptible for the "fine" ventricular fibrillation. Rhythms that are not defibrillated are proven (agonal) asystole and pulseless electrical activity (PEA), often called electromechanical dissociation. In asystole or development of the block, one can try with percutaneous stimulation, by applying the thoracic electrodes or by administering the above mentioned adrenaline. The new recommendations suggest that the administration of $3 \mathrm{mg}$ atropine in bolus is of a little effect (although we still apply it in certain situations as a potent vagolytic).

According to the new guidelines of the European Resuscitation Counci ${ }^{22,23}$, published in 2010, the survival after cardiac arrest with asystole or pulseless electrical activity is less likely if causes are not immediately detected and resolved (as it is pericardial tamponade here). In case of a true asystole there is no use of electrical stimulation, which is a consensus of experts at an international level.

In contusion-related cardiac injuries no other in-hospital measures, such as the temporary introduction of hypothermia $32-34^{\circ} \mathrm{C}$ were considered necessary, if a patient was not in a coma and had no neurological disorders after the cardiac arrest. The current recommendation is that the condition after the cardiac arrest is treated by hypothermia. Mechanical ventilation with myorelaxants and sedation is very rarely required, and the today modern mechanical support to cardiovascular system by apparatus VAD, BIVAD, LVAD, RVAD, LVAS - HEART MTTE II etc. is extremely rarely used.

All the symptoms and clinical status depend on the size of the injured myocardial mass, which will lead to asystole and irreparable cardiac arrest. The destruction of $>50 \%$ of myocardial mass is very risky ${ }^{24}$. RV is more exposed to injuries in case of chest contusions, while its myocardial mass is lower than that of the LV, so the increase in myocardial specific enzymes and troponins, despite a strong force can therefore be slight which does not contribute to the assessment of severity of clinical course of the disease ${ }^{5}$.

Blunt chest trauma with myocardial contusion is statistically more common than penetrating injury, but it seems to be directly less dangerous to life. A frequently asked question is posed in connection with a sudden death of athletes who have experienced many minor or major blunt chest traumas, for instance football players (falls, collisions, blow to the chest by a ball, etc.), who previously underwent cardiac examinations and had no proven common causes of sudden cardiac death. A small number of taken ECGs in case of collapse or syncopes sustained by the players on the playground indicate a malignant ventricular tachycardia, which may be related to the earlier blunt trauma? If the blunt chest trauma is followed by the development of resistant hypotension despite an adequate resuscitation of hypovolemia, and if no other obvious cause of the condition is present, an additional coronary angiography should be performed ${ }^{21}$.

\section{Other emergency interventions in cardiac trauma}

The diagnosis of the cardiac trauma, particularly penetrating cardiac trauma, should be made as soon as possible after the sustained incident, because the emergency intervention when suspecting the development of pericardial tamponade may save the life of the injured and is the prerequisite for successful resuscitation if cardiac arrest occurs. The appar- 
na prsnom košu, već inspekcijom upućuje na vrlo vjerojatnu i razderotinu, ranu srca. Ako se radi o ozljedi vatrenim projektilom potrebno je utvrditi i izlaznu ranu, kako bi se mogao predvidjeti put projektila i oštećenje drugih organa na tom putu te ocijeniti zadržavanje projektila u nekom od organa. Pogodak u samo rebro ili sternum projektilom ili nožem dovodi do rasprsnuća koštanih struktura te upućuje i na laceraciju srca. Procjena stanja pacijenta s takvom ozljedom mora se, dakako, temeljiti na uobičajenom planu zbrinjavanja i algoritmu pristupa za akutne hitne incidente, koji traži reanimaciju označenu akronimom ABCDE - Airway, Breathing, Circulation, Defibrillation odnosno Disability, Expose (osloboditi dišne puteve, procijeniti disanje, primijeniti umjetno disanje, dok se primjena ručne masaže preko donjeg dijela sternuma kod sumnje na tamponadu dakako ne savjetuje, nego dolazi u obzir procjena pulsa, tlaka, cirkulacije, a defibrilaciju u slučaju ventrikulske tahikardije i fibrilacije treba učiniti odmah, ako nema reakcije na medikamentnu terapiju primijenjenu i.v. ili intraosealno $0^{6,22,23}$. Više se ne preporuča davanje lijekova intratrahealno zbog slabe resorpcije.

Ljestvica traumatskih oštećenja prsnog koša i srca ima šest stupnjeva i detaljno je opisana u literaturi ${ }^{24}$.

Ishod penetrantne i nepenetrantne ozljede ovisi od tri čimbenika: 1. brzina pružanja pomoći na mjestu incidenta; 2. stručnost i opremljenost ekipe HMP; 3. brzina transporta uz neophodno obavještavanje ekipe u kirurškom centru za primitak i intervenciju traumatiziranog ${ }^{1,5,12,13,18-21,25}$.

Stanje unesrećenog s penetrantnom ozljedom srca na mjestu nesreće u dijagnostičkom je pogledu složeno. Može biti već prisutan kardiogeni šok s distendiranim jugularnim venama ili /i hipovolemički šok (kada je ta distenzija slabije izražena), a što sve upućuje na brzi razvoj smrtne tamponade perikarda kod vidljive rane na prsnom košu.

Oštećenje projektilom velikog kalibra iz vatrenog oružja ili široke ubodne rane dovode u većini incidenata do trenutne smrti, dok oštećenje projektilom malog kalibra i ubodne rane oštrim, uskim predmetom (frakturirano rebro, dio - iversternuma, vrh noža) mogu se liječiti i spriječiti tamponadu. Kod malog projektila, ulazna rana ne mora biti vidljiva na prvi pogled, jer se kao mala ekhimoza između dva rebra, lako previdi. Upravo takve male, "nevidljive" ulazne rane mogu imati kobne posljedice. EKG zapis u toj situaciji s nastalom tamponadom, daje gotovo uvijek, pa i u malom penetrantnom oštećenju miokarda, sliku perakutne lezije ili ishemije miokarda s eleviranom ST-spojnicom, najčešće konkavnom na samom vrhu elevacije - upravo slično nalazu u prvim satima perakutnog infarkta miokarda, koji inače rijetko viđamo (jer se već u akutnoj fazi infarkta nalazi samo konveksna ST-elevacija). Konkavnost na vrhu elevirane STspojnice je suprotna glavnoj el. osi T-vala, koji u početku te male ozljede može biti i pozitivan ${ }^{26}$. Slijedi inverzija T-vala te se takav bolesnik obično smješta u intenzivnu skrb i najčešće liječi kao infarkt miokarda. Manja disrupcija miokarda od manjeg projektila može privremeno, spontano trombozirati. Međutim, na temelju krivo postavljene dijagnoze infarkta bolesniku započinje se liječenje koje dovodi (ovdje s pravom kažemo nažalost) do trombolize već stvorenog tromba na mjestu razderotine i daljnji razvoj tamponade srca te bolesnik umire u intenzivnoj skrbi neutvrđene dijagnoze.

Stoga za točnu procjenu stanja prijeteće tamponade srca, kod penetrantne i nepenetrantne ozljede prsnog koša, liječnik HMP (prema europskim preporukama za reanimaciju) na mjestu incidenta mora imati pri ruci prenosivi ehokardiografski aparat te se njime odmah orijentirati (kao što čini EKG- ent wound, chest laceration is a sign for a very probable tear and cardiac injury as determined by the examination. In the case of an injury caused by fire missile, it is necessary to determine the entry and exit wound, in order to be able to predict the path of missile and injury of other organs in this path, and assess the retention of the missile in some of the organs. A blow to the rib only or sternum by a missile or a knife leads to bursting of bone structure indicating thus the cardiac laceration. The assessment of the patient's condition with such an injury must, naturally, be based on the usual management plan and algorithm for acute emergency incidents, requiring resuscitation indicated as acronym $A B$ CDE - Airway, Breathing, Circulation, Defibrillation and Disability Expose (free airways, assess breathing, apply artificial respiration, while the use of manual massage over the lower part of the sternum when suspecting tamponade is certainly not advised. However, the evaluation of pulse, blood pressure and circulation will be taken into consideration, while defibrillation is to be performed immediately in case of ventricular tachycardia and fibrillation, if there is no response to medicamentous therapy administered i.v. or intraosseously ${ }^{6,22,23}$. Administration of medicines intratracheally is no longer advisable due to poor absorption.

The scale of traumatic injuries of the chest and heart has six degrees and it is described in the literature ${ }^{24}$.

The outcome of penetrating and non-penetrating injury depends on the three factors: 1. promptness in providing assistance on the spot of the incident; 2 . expertise and equipment of EMS team; 3 . the speed of transport accompanied by providing information to the surgical center about the necessity to admit and manage the traumatized person $n^{1,5,12,13,18-21,25}$.

The condition of the injured with a penetrative cardiac injury on the spot of an incident is complex in terms of diagnostics. Cardiogenic shock with distended jugular veins and/or hypovolemic shock (when this distension is slightly pronounced) may be present, indicating the rapid development of fatal pericardial tamponade in visible chest wounds.

Damage caused by a large caliber missile from firearms or a wide stab wound in most incidents result in the immediate death, while the damage caused by a small caliber missile and stab wounds caused by a sharp, narrow object (fractured rib, part - body of sternum, tip of a knife) can be treated with prevention of tamponade. In a case of a small missile, the entry wound may not be apparent at a first glance, because it is easily overlooked as a small ecchymosis between the two ribs. Such small, "invisible" entry wounds can have fatal consequences. ECG recording in this situation with the developed tamponade gives almost always, even in a minor penetrative myocardial injury, an image of percutaneous lesion or myocardial ischemia with ST-segment elevation, usually concave at the top of the elevation - similar to a finding in the first hours of percutaneuous myocardial infarction, which we otherwise can rarely see (because already in the acute phase of myocardial infarction we can only see a convex ST-elevation). The concavity at the top of the ST-segment elevation is opposite to the main el. axis of the T-wave, which in case of a minor injury can initially be even positive ${ }^{26}$. It is followed by T-wave inversion, and such a patient is usually referred to the intensive care unit and is often treated as myocardial infarction. Minor myocardial disruption caused by a small missile can be temporarily spontaneously thrombosed. However, should the faulty diagnosis of infarction in the patient be made, the treatment will begin (here we are right to say unfortunately) resulting in a thrombolysis of the already created thrombus at the site of laceration and further development of cardiac tamponade, and the patient dies in the intensive care unit with undetermined diagnosis. Therefore, for accurate assessment of the condition of lifethreatening cardiac tamponade, in case of penetrating and non-penetrating chest trauma, the EMS physician (according to the European guidelines on resuscitation) must at the spot of the incident have portable echocardiography device 
om o ritmu i frekvenciji srca) o stanju, količini perikardijskog sadržaja, ali ev. i o laceraciji miokarda, perikarda te stanju srčanih šupljina. Potom slijedi eventualno i terapijski postupak da se pokuša takvog bolesnika s prijetećom ili već izraženom tamponadom perikarda spasiti terapijskom perikardiocentezom koja nije samo zahvat za kardiologa i kardiokirurga nego je u ovim iznimnim slučajevima stručni zadatak za koji treba biti osposobljen liječnik HMP, uz pomoć i asistiranje medicinske sestre ili tehničara.

Medicinska doktrina kaže: "osim u hitnim slučajevima tamponade perikarda, terapijsku perikardiocentezu, koja je potencijalno i opasna, treba učiniti pod kontrolom ultrazvuka srca u prostoriji za kateterizaciju srca." Na mjestu incidenta nema sobe za kateterizaciju, to može biti doduše dobro opremljeno, adaptirano vozilo HMP, ali je praktičnije, brže, učinkovitije terapijsku perikardiocentezu učiniti neposredno uz ležećeg bolesnika vani, što je dopušteno citiranom doktrinom (i opisano kao uspješno). Ako liječnik HMP utvrdi perikardijski sadržaj koji oblaže miokard iza LV i ispred DV s fenomenom "lelujajućeg" srca ("swinging heart" — srca koje se impresivno klati), a što je u akutnim slučajevima izraz velikog izljeva koji aproksimativno prelazi $1.500 \mathrm{~mL}$, uz pomoć asistenta, koja drži glavu sonde ultrazvuka i "osvjetljava" srce, liječnik bi trebao dužom iglom i većom štrcaljkom 100-200 mL, učiniti punkciju perikarda, pristupom iz subksifoidnog područja, subkostalno lijevo, s usmjerenjem punkcijske igle prema gore i lijevom ramenu, pod kutom od 30 stupnjeva. Poželjno je da se bolesnika postavi u polusjedeći položaj ili u ležeći na desnom boku. Taj zahvat s aspiracijon i $100 \mathrm{~mL}$ perikardijskog sadržaja spašava život unesrećenog i omogućuje "kupovanje vremena" za transport do kirurškog centra. Evakuacija i samo $50 \mathrm{~mL}$ već dovodi ponekad do olakšanja i često zaustavlja razvoj tamponade.

Drugi problem, koji završava smrtno u danim okolnostima je nastup asistolije kada (pored mogućnosti perkutane stimulacije) u većoj udaljenosti od kirurških centara treba dati prednost, uvođenju privremenog električnog stimulatora srca preko centralnog venskog sustava gornje šuplje vene, vene subklavije ili unutarnje jugularne, vene cefalike. Zahvat treba učiniti također odmah uz ležećeg pacijenta, bez radiološke pomoći (koja se zbog hitnosti uz dobro iskustvo liječnika ne koristi uvijek ni u jedinicama intenzivne skrbi). Implantacija centralnog venskog katetera istim pristupom daje ujedno informaciju o visini centralnog venskog tlaka u šupljinama desnog srca, o ev. hipovolemiji što usmjeruje i određuje daljnju terapiju ${ }^{27}$. Istim venskim pristupom, u vrijeme hospitalizacije u intenzivnoj skrbi, može se implantirati i Swan Ganzov kateter te ga plasirati preko trikuspidnog ušća u plućnu arteriju, s kratkotrajnom opstrukcijom arterije da se izmjeri visina plućnog kapilarnog tlaka koji je jednak tlaku u LA (normalno do $10 \mathrm{mmHg}$ ). Time se ujedno dobije procjena stanja miokarda LV, teledijastoličkog tlaka u LV kao izraz teledijastoličkog volumena i kontraktilnosti. Kod tog zahvata postoji mogućnost oštećenja trikuspidnog zalistka te zadnje vrijeme postoje kontroverze o tome poboljšava li preživljavanje.

Ovdje je iznesen moderan pristup tretmanu prijeteće tamponade srca, koji se sprovodi u razvijenim europskim zemljama i traži stručnost i materijalno ulaganje u opremljenost HMP. on him as to immediately define (as rhythm and heart rate are determined by the ECG) the condition, quantity of pericardial fluid and any myocardial or pericardial lacerations and condition of the heart cavities. This may be followed by therapeutic procedure attempting to save such a patient with life-threatening or already pronounced pericardial tamponade by performing therapeutic pericardiocentesis which is not only an intervention to be performed by a cardiologist and cardiac surgeon, but in these exceptional cases, this is the task that is to be performed by a qualified EMS physician, with the help and assistance of a nurse.

Medical doctrine says, "except in emergency cases - pericardial tamponade, therapeutic pericardiocentesis, which may be dangerous, should be done under heart ultrasound in a room for a heart catheterization." On the spot of the incident there is no room for catheterization, but this may be a well equipped, adjusted EMS vehicle anyway, although it is more convenient, faster, more effective to perform therapeutic pericardiocentesis directly next to the lying patient outside, as permitted by the quoted doctrine (and described as successful). If the EMS physician determines pericardial content coating the myocardium behind the LV and in front of the RV with the phenomenon of "swinging heart" - the heart which impressively swings), which is in acute cases the expression of a large effusion that approximately exceeds $1.500 \mathrm{~mL}$, the physician should with the help of an assistant who keeps the head of the ultrasound probe and "illuminates" the heart, use a longer needle and syringe of $100-200 \mathrm{~mL}$ to do the pericardial puncture via the left subxiphoid subcostal region, directing the punctuation needle upwards and left shoulder, at an angle of 30 degrees. It is desirable to place the patient in a semi-sitting position or lying on the right side. This procedure with aspiration and $100 \mathrm{~mL}$ of pericardial content will save the life of the injured and allows "buying time" for transportation to the surgical center. The evacuation and only $50 \mathrm{~mL}$, already results in relief and often stops the development of the tamponade.

The second problem resulting in fatal outcome in the given circumstances is the development of asystole when (in addition to a possibility of percutaneous stimulation) at a greater distance from the surgical centers the priority should be given to the introduction of temporary electrical pacemaker via a central venous system of superior vena cava, subclavian vein or internal jugular, cephalic vein. The procedure should be also done immediately with the lying patient, without radiological assistance (which is due to the urgency with the good experience of a physician not always used even in intensive care units). The implantation of central venous catheter by the same approach also gives information on the central venous pressure in the right heart cavities and on any hypovolemia which directs and determines a further treatment ${ }^{27}$. The Swan-Ganz catheter may be implanted and placed by the same venous access at the time of hospitalization in the intensive care unit via the tricuspid orifice into the pulmonary artery, with a short-term obstruction of the artery as to measure the pulmonary capillary pressure that is equal to the pressure in LA (normal up to $10 \mathrm{mmHg}$ ). This is how we obtain an assessment of the condition of the LV myocardium, telediastolic pressure in the LV as an expression of telediastolic volume and contractility. Regarding this procedure, tricuspid valve may be damaged and recently there are controversies about whether it improves survival.

Here we present a modern approach to the treatment of threatening cardiac tamponade, which is performed in developed countries and requires expertise and material investment in the EMS equipment. 


\section{Dijagnostičke metode kod tupe i oštre traume prsnog koša (u hospitalizaciji)}

1. Radiološkim pregledom prsnog koša otkriva se pneumotoraks, pneumoperikard, hemotoraks te medijastinalno proširenje zbog hematoma. Konvencionalna snimka i profil prsnog koša ne može prikazati miokardnu kontuziju, valvularno oštećenje, niti dokazati postojanje manjeg perikardijskog sadržaja. Perikardijski izljev tek u količini većoj od $200 \mathrm{~mL}$ kod snimanja u ležećem položaju "nalije se" na gornji dio velikih žila i daje sjenu sličnu trapezu. U projekciji stojeći daje "sjenu srca kruškolikog izgleda - praznih pluća".

2. Angiografija koronarnih arterija primjenjuje se rijetko, ako stanje unesrećenog dopušta u nerazjašnjenoj hipotenziji, a u korigiranoj hipovolemiji da se otkrije oštećenje intime, prisutno neposredno poslije traume te u kasnijem tijeku tromboza, okluzija koronarnih arterija, disekcija ili aneurizmatsko proširenje.

3. EKG zapis kod traume, osim aritmija, pokazuje druge nespecifične nalaze ST-segmenta. Nalaz promjena ST-segmenta i T-vala je sličan za perikardno-miokardno oštećenje kod tupe traume nalazu nekih oblika srčanog infarkta, miokardne ishemije, lezije. Kod penetrantne traume prisutni su češće znakovi nekroze q- i QS- zupci.

4. Lijevom i desnom kateterizacijom srca dobiju se detaljne informacije o stanju srčanih valvula, funkciji, intrakardijalni tlakovima Pretraga ne spada u red prvog dijagnostičkog izbora i treba biti dobro indicirana. U velikom hematoperikardu, koji nije tretiran terapijskom perikardiocentezom, niti se ima mogućnosti kiruški intervenirati, već Swan-Ganzovim kateterom, dobiju se informacije o tlakovima desne strane srca.

5. Transtorakalna ehokardiografija (TTE) je visoko osjetljiva i specifična pretraga za otkrivanje i malih količina perikardijskog sadržaja ${ }^{28}$. Nije specifična za diferencijaciju sadržaja - eksudat, transudat (hidroperikard), hemoperikard, hiloperikard (ruptura duktusa toracikusa) i manje je osjetljiva za otkrivanje manjih ruptura, laceracija miokarda i perikarda. Diferencijalna dijagnoza navedenih kvaliteta perikardijskog sadržaja moguća je samo dijagnostičkom perikardiocentezom uz pomoć ultrazvuka i potom dopunskim analizama. Međutim, ta se pretraga (u tu svrhu) rutinski ne primjenjuje. Dijagnostička perikardiocenteza uz pomoć ultrazvuka srca u maloj količini perikardijskog sadržaja inače je visoko rizična, makar je izvodio kardiolog, kardiokirurg (opisan je 2012. godine slučaj bolesnice kod koje je u jednom američkom sveučilišnom centru u dijagnostičkoj perikardiocentezi učinjena perforacija DV, kod malog perikardijalnog sadržaja ${ }^{25}$ ).

6. Transezofagijska ehokardiografija je osjetljivija metoda od TTE u procjeni nekih parametra, ali u okolnostima prsne traume, zbog čestog oštećenja ezofagusa i kralježnice, nije prikladna za primjenu.

7. Magnetna rezonancija (MR) srca je dobrodošla dijagnostička metoda u mirnom post-traumatskom razdoblju u hospitalizaciji u kirurškom centru radi razjašnjenja atipičnih posttraumatskih prsnih simptoma ${ }^{29}$. U akutnoj fazi traume zbog dugog trajanja je praktički neprimjenjiva. Osjetljivost MR u procjeni stupnja kontuzijskog oštećenja miokarda, s nekrozom ili bez nje, poremećajem kontraktiliteta sa segmentnim ispadanjima, ocjenom hibernacije šireg perinekrotičnog područja miokarda te procjenom vijabilnosti miokarda, visoka je i veća od TTE.

8. Detaljnija procjena kinetike stijenke miokarda, uključujući akineziju, hipokineziju te vijabilnost s visokom senzitivnošću donose nuklearne metode (PET, SPECT).

\section{Diagnostic methods for blunt and sharp chest} trauma (in hospitalization)

1. Radiological examination of the chest reveals a pneumothorax, pneumopericardium, hemothorax and mediastinal widening due to hematoma. Conventional image and profile of the chest can not show myocardial contusion, valvular injury, or prove the existence of a minor pericardial fluid. Pericardial effusion only in quantities over $200 \mathrm{~mL}$ in case of recording in the lying position "is poured" onto the upper part of the large vessels and a provides a shadow similar to trapeze. In the standing projection it gives a "shadow of the pear-shaped heart - empty lungs".

2. The angiography of the coronary arteries is applied rarely, if the condition of the injured in unclear hypovolemia and corrected hypovolemia allows the detection of the damage to the intima, present immediately after the trauma and in thrombosis in the subsequent course, coronary artery occlusion, dissection or aneurysmal expansion.

3. ECG recording in trauma, except in arrhythmia, shows some other non-specific ST-segment results. The finding of changes to ST-segment and T-wave is for pericardial-myocardial injury in blunt trauma similar to the finding of some forms of cardiac infraction, myocardial ischemia, lesions. Signs of necrosis q-and QS-waves are more often present in penetrating trauma.

4. Left and right heart catheterization gives us some detailed information on the condition of heart valves, function, intracardiac pressures. The examination is not considered to be the first diagnostic choice and should be well indicated. In case of major hemopericardium, which is not treated by therapeutic pericardiocentesis, and which is not to be surgically managed, but where we can use Swan-Ganz catheter, we obtain information on the pressures of the right side of the heart.

5. Transthoracic echocardiography (TTE) is a highly sensitive and a specific test for detecting even small amounts of pericardial fluid ${ }^{28}$. It is not specific for differentiation of the fluid - exudate, transudate (hydropericardium) hemopericardium, chylopericardium (rupture of the ductus toracicus) and is less sensitive for detecting minor ruptures, myocardial and pericardial lacerations. Differential diagnosis of the above indicated qualities of pericardial content can only be made by diagnostic pericardiocentesis under ultrasound guidance followed by additional analyses. However, this test (for this purpose) is not applied routinely. Diagnostic pericardiocentesis is under heart ultrasound guidance in a small quantity of pericardial fluid highly risky, although it is performed by a cardiologist, cardiac surgeon (it was described in 2012 case report of a patient with a small pericardial fluid who in one American university center underwent diagnostic pericardiocentesis resulting in RV perforation ${ }^{25}$ ).

6. Transesophageal echocardiography is more sensitive method than TTE in the evaluation of some parameters, but in the circumstances of thoracic trauma it is not suitable for use due to frequent damage to the esophagus and spine.

7. Magnetic resonance imaging (MRI) of the heart is a welcome diagnostic method in a quiet post-traumatic period of hospitalization in a surgical center for clarification of atypical post-traumatic thoracic symptoms ${ }^{29}$. It is practically inapplicable in the acute phase of trauma due to the long duration. The sensitivity of MRI in the evaluation of the degree of myocardial injury caused by contusion with necrosis or without it, contractility disorder with segment failure, assessment of hibernation of a wider perinecrotic region of the myocardium and assessment of myocardial viability is high and higher than TTE. 
9. MSCT i CT prsnog koša i srca su praktički nezaobilazne metode u hospitalnom razdoblju zbog izvrsne kontrastne rezolucije i kratkog trajanja pregleda. Daju odgovore o ev. zahvaćenosti ostalih organa u prsnom košu, trbuhu, a može se dodatno i točno procijeniti ev. zaostalu količinu hematoperikarda nakon terapijske perikardiocenteze. Metoda otkriva i minimalnu laceraciju miokarda, perikarda — diskontinuitet njegovih granica, manja udubljenja na perikardu, rupturiranu dijafragmu, hernijaciju trbušnih organa u prsni koš i srčanu luksaciju, strangulaciju srčanih struktura i velikih žila, strano tijelo ev. zaustavljen u organima, pneumotoraks, pneumoperikard, pleuralne izljeve, interpoziciju plućnog parenhima između aorte i plućne arterije, između srca i dijafragme ili i DA i izgonskog trakta DV.

\section{Zaključak}

Namjera ovog članka bila je ukazati na povećanu incidenciju nastanka tamponade perikarda različite etiologije - zbog penetrantne (oštre) i nepenetrantne (tupe) ozljede srca, danas ipak najčešće kao posljedica "epidemije" prometnih nesreća. Naglašena je potreba pravodobne prehospitalne dijagnostike i intervencije visokostručnog i educiranog medicinskog osoblja, po mogućnosti na mjestu same traume, koja spašava život unesrećenog.

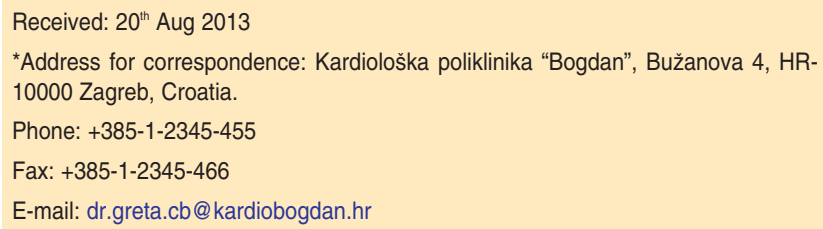

8. A more detailed assessment of the kinetics of myocardial wall, including akinesia, hypokinesia and viability with high sensitivity is made by nuclear methods (PET, SPECT).

9. MSCT and CT of the chest and heart are practically unavoidable methods in the in-hospital period due to excellent contrast resolution and short duration of the examination. They provide answers about other organs potentially affected in the chest, abdomen, and residual amount of hemopericardium after therapeutic pericardiocentesis is to be additionally accurately assessed. The method detects even minimal laceration of the myocardium and pericardium - discontinuity of its borders, smaller recesses in the pericardium, ruptured diaphragm, herniation of abdominal organs into the chest and cardiac luxation, strangulation of cardiac structures and large vessels, a foreign body potentially stopped in the organs, pneumothorax, pneumopericardium, pleural effusions, interposition of the lung parenchyma between the aorta and pulmonary artery, between the heart and the diaphragm, or both RA and RV outflow tract.

\section{Conclusion}

The purpose of this Article was to point to an increased incidence of development of pericardial tamponade of various etiology - caused by penetrating (sharp) and non-penetrating (blunt) cardiac injury, today still usually as a result of "epidemic" of car accidents. The need for prompt pre-hospital diagnosis and intervention by highly qualified and trained medical personnel, preferably on the spot of the trauma, that saves life of an injured person is emphasized.

\section{Literature}

1. Co SJ, Yong-Hing CJ, Galea-Soler S, et al. Role of imaging in penetrating and blunt traumatic injury to the heart. Radiographics. 2011;31:E101-E115.

2. Velinović M, Velinović D, Vraneš M, et al. Heart injuries — still a challenge for cardiac surgery. Open Cardiovasc Thorac Surg J. 2009;2:38-42.

3. Salehian O, Teoh K, Mulji A. Blunt and penetrating cardiac trauma: a review. Can J Cardiol. 2003;19(9):1054-9.

4. Roxburg JC. Myocardial contusion. Injury. 1996;27(9):603-5.

5. Bertinchant JP, Polge A, Moihty D, et al. Evauation of incidence, clinical significance and prognosis values of circulation cardiac troponin I and T elevation in hemodynamically stable patients with suspected myocardial contusion after blunt cerebral trauma. J Trauma. 2000;48:924-31.

6. Biffl WL, Moore EE. Blunt cardiac injury. http://dx.doi.org/10.1007/978-1-4615-1127-4_37

7. Mediastinoscopy. http://www.health.harvard.edu/diagnostic-tests/mediastinoscopy.htm (30.6.2013)

8. Sheren PB, Galloway R, Healy M. Blunt traumatic pericardial repture and cardiac herniation with a penetrating twist: two case reports. Scand J Trauma Resusc Emerg Med. 2009 Dec 15;17:64.

9. Tanaka H, Fuhta T, Endoh J, Kobajashi K. Pericardial tamponade type injury: a 17-year study in an urban trauma center in Japan. Surg Today. Jpn J Surg. 1999;29:1017-23.

10. Bogdan I. Elektrokardiogram u akutnom traumatskom oštećenju srca. U: Duraković Z i sur. Elektrokardiogram. 2. izdanje. Zagreb: Grafos (Manualia Universitatis Studiorum Zagrabiensis), 2003.

11. Matraci I, Polat A, Cevirme D, et al. Increasing numbers of penetrating cardiac trauma in a new center. Ulus Travma Acil Cerrahi Derg. 2010;16(1):54-8.

12. Purcaro A, Constantini C, Ciampani N, et al. Diagnostic criteria and management of subacute ventricular free wall rupture complicating acute myocardial infarction. Am J Cardiol. 1997;80(4):397-405

13. Groh J, Sunder-Plassman K. Heart dislocation following extensive lung resection with partial pericardial resection. Anesthetist. 1987;36(4):182-4.

14. Moore EE, Malangoni MA, Cogbill TH, et al. Organ injury scaling IV: Thoracic vascular, lung, cardiac and diaphragm. J Trauma. 1994;36:299-300.

15. Guan DW, Oshima T, Jia JT, Kondo T, Li D. Morphological findings of "cardiac contusion" due to experimental blunt impact to the precordial region. Forensic Sci Int. 1999;100(3):2011-20.

16. Bogdan I. Elektrokardiogram u akutnom traumatskom oštećenju srca. U: Duraković Z i sur. Elektrokardiogram. 2. izdanje. Zagreb: Grafos (Manualia Universitatis Studiorum Zagrabiensis), 2003, 265-268

17. Armstrong WT, Ryan T. In: Feigenbaum's Echocardiography. Seventh Edition. Philadelphia: Lippincott and Wilkins, 2010, $248-253$.

18. Gaspari MG, Lorelli DR, Kralovich KA, Patton HLJr. Physical examination plus chest radiography in penetrating periclavicular trauma: the appropriate trigger for angiography. J Trauma. 2000;46(6):1029-33.

19. Van Horn JM. A case study of right ventricular rupture in a elderly victim of motor vehicle crush incorporating end-of-life care into trauma nursing. J Trauma Nurs. 2007;14(3):13643.

20. Pretre R, Chilcott M. Blunt trauma to the heart and great vessels. N Engl J Med. 1997;336(9):626-32.

21. Pringle SD, Davidson KG. Myocardial infarction caused by coronary artery damage from blunt chest injury. Br Heart J. 1987;57(4):375-6.

22. Koster RW, Baubin MA, Bossaert LL, et al. European Resuscitation Council Guidelines for Resuscitation. Resuscitation. 2010;81(10):1277-92.

23. Deakin CD, Morrison LJ, Morley PT, et al. International Consensus on Cardiopulmonary Resuscitation and Emergency Cardiovascular Care Science with Treatment Recommendations. Resuscitation. 2010;81Suppl 1:e93-e-174.

24. Organ injury scaling. Cardiac. http://www.trauma.org/archive/scores/ois-heart.html (30.6.2013)

25. Bogdan I. Upalne bolesti endokarda, miokarda i perikarda. U: Bogdan I. Kardiološki priručnik s primjerima. Zagreb: Stega tisak d.o.0., 2012. 
26. Liedtke AJ, Gault JH, Demuth WE. Electrocardiographic and hemodynamic changes following nonpenetrating chest trauma in the experimental animal. Am J Physiol. 1974;226(2):377-82

27. Rubinjoni T, Nikolić V, Tudman Z, Bogdan I, Dusper B. Važnost centralnog venskog tlaka u restituciji hipovolemijskog stanja. Lijec Vjesn. 1978;100(2):123-7.

28. Jurij R, Božić I. Elektrokardiografija. Zagreb: Medicinska naklada, 2007.

29. Southam S, Jutila C, Keta L. Contrast-enhanced cardiac MRI in blunt cjest trauma differentiating cardiac contusion from acute peritraumatic myocardial infarction. J Thorac Imaging. 2006;21(2):176-8. 